\title{
The Utilization of E-Learning for Improving Knowledge on Covid-19 Prevention and Control for Paramedics at Permata Bunda Hospital in Medan
}

\author{
Masrul $^{1}$, Sahat Halim ${ }^{2}$ \\ ${ }^{1}$ Division of Gastroenterology, Department of Internal Medicine, Faculty of Medicine, University of Sumatera \\ Utara, Medan 20155, Indonesia \\ ${ }^{2}$ Department of Internal Medicine, Faculty of Medicine, University of Sumatera Utara, Medan 20155, Indonesia
}

Corresponding Author: Masrul

\begin{abstract}
Coronavirus-19 (COVID-19) has been declared a world pandemic by WHO. This virus and disease are known to have started in the city of Wuhan, China since December 2019. As of March 21, 2020, the number of cases of this disease has reached 275,469 people, spread across 166 countries, including Indonesia. Prevention is the key to deciding the transmission process so it is necessary to carry out a process of increasing knowledge through an e-learning system.

Method: This research is analytic with cross sectional design with 188 participants. This study uses a questionnaire measuring tool that is accessed online and analyzed into univariate and bivariate

Result: The use of e-learning has proven to be an effect in increasing paramedics' knowledge about COVID-19. From the results of Wilcoxon analysis, there are differences in knowledge before and after the use of e-learning. The average post-test score has increased by about 72 when compared to the pre-test mean score.

Conclusion: Some paramedics already have good knowledge about COVID-19, but the use of e-learning has proven to be effective in increasing paramedic knowledge.
\end{abstract}

Keywords: COVID-19, e - learning, knowledge

\section{INTRODUCTION}

Coronavirus-19 (COVID-19) has been declared a world pandemic by WHO. Coronaviruses are zoonoses or viruses that are transmitted between animals and humans. This virus and disease are known to have started in the city of Wuhan, China since December 2019. As of March 21, 2020 , the number of cases of this disease has reached 275,469 people spread across 166 countries, including Indonesia. The President of the Republic of Indonesia has declared the status of this disease to be the Emergency Response stage on March 17, 2020. The President has also issued Presidential Decree No. 7 of 2020 concerning the Task Force for the Acceleration of Handling Corona, chaired by the Head of the National Disaster Management Agency (BNPB). This Task Force aims to increase national resilience in the health sector. ${ }^{1}$

As of March 25, 2020, 414,179 confirmed cases were reported with 18,440 deaths (CFR 4.4\%) with cases reported in 192 countries / territories. Among these cases, several health workers were reported to be infected. On March 2, 2020, Indonesia reported 2 confirmed cases of COVID-19. As of March 25, 2020, Indonesia has reported 790 confirmed cases of COVID-19 from 24 provinces. ${ }^{2,3,4}$

The advancement of information technology encourages changes in the learning process known as e-learning which brings transformational changes in the field of education in digital form both in content and in systems. Learning in the form of elearning is needed during this pandemic in 
order to increase COVID-19 knowledge for paramedics. $^{5}$

For this reason, we chose this community service activity in the form of using e-learning to increase knowledge about the prevention and control of Covid19 for the Medical Team and Paramedics at Permata Bunda Hospital Medan.

\section{METHODS}

This research is descriptive analytic with cross sectional design. The participants of this study were paramedics who worked at Permata Bunda Hospital in Medan with a total of 188 participants. The inclusion criteria in this study were paramedics who worked at Permata Bunda Hospital who had a smartphone with the WhatsApp application.

The collection of participants in this study was to distribute flyers containing information about the time and place for the implementation of the activity and then data collection of participants who would take part in e-learning activities regarding COVID-19. This research took place from April-October 2020. Participants' knowledge can be measured by using questionnaire measuring tool to be distributed online using an online application. In addition to extension activities, participants will be required to take a pre-test and post-test using an online application to assess knowledge.
Data analysis was performed by univariate and bivariate (Wilcoxon test) using SPSS edition 21th (SPSS Inc. Chicago). A $\mathrm{P}$ value $<0.05$ with a $95 \%$ confidence interval was considered statistically significant.

\section{RESULT}

The results of this study indicate that some paramedics have good knowledge about COVID-19. However, there are still many paramedics who have low knowledge about COVID-19, which is indicated by an average pretest score of 54 compared to an average post-test score of 72 . The post test shows that the use of E learning is very useful in increasing paramedical knowledge about COVID-19.

Table 1. Value of knowledge before and after counseling

\begin{tabular}{|l|l|l|l|}
\hline \multicolumn{2}{|c|}{ Table 1. Value of knowledge before and after counseling } \\
\hline \multirow{2}{*}{$\mathrm{N}$} & Valid & pretest & posttest \\
\cline { 2 - 4 } & Missing & 188 & 188 \\
\hline Mean & 0 & 0 \\
\hline Mode & 54,7447 & 72,4202 \\
\hline Minimum & 73.00 & 73.00 \\
\hline Maximum & 23.00 & 38.00 \\
\hline
\end{tabular}

The pretest value was assessed before counseling for paramedics with the lowest pretest score of 23 as many as 7 people (3.7\%) and the highest score of 88 as many as 2 people $(1.1 \%)$. The highest score owned by participants was 73 as many as 32 people $(17 \%)$. From the results of this pretest score, we can see that some paramedics already have good knowledge about COVID-19.

Table 2. Pre test values

\begin{tabular}{|c|c|c|c|c|c|}
\hline & & Frequency & Percent & Valid Percent & Cumulative Percent \\
\hline \multirow{19}{*}{ Valid } & 23.00 & 7 & 3.7 & 3.7 & 3.7 \\
\hline & 27.00 & 24 & 12.8 & 12.8 & 16.5 \\
\hline & 31.00 & 11 & 5.9 & 5.9 & 22.3 \\
\hline & 35.00 & 10 & 5.3 & 5.3 & 27.7 \\
\hline & 38.00 & 11 & 5.9 & 5.9 & 33.5 \\
\hline & 42.00 & 2 & 1.1 & 1.1 & 34.6 \\
\hline & 46.00 & 9 & 4.8 & 4.8 & 39.4 \\
\hline & 50.00 & 7 & 3.7 & 3.7 & 43.1 \\
\hline & 54.00 & 6 & 3.2 & 3.2 & 46.3 \\
\hline & 58.00 & 4 & 2.1 & 2.1 & 48.4 \\
\hline & 62.00 & 15 & 8.0 & 8.0 & 56.4 \\
\hline & 65.00 & 7 & 3.7 & 3.7 & 60.1 \\
\hline & 69.00 & 17 & 9.0 & 9.0 & 69.1 \\
\hline & 73.00 & 32 & 17.0 & 17.0 & 86.2 \\
\hline & 77.00 & 15 & 8.0 & 8.0 & 94.1 \\
\hline & 81.00 & 5 & 2.7 & 2.7 & 96.8 \\
\hline & 85.00 & 4 & 2.1 & 2.1 & 98.9 \\
\hline & 88.00 & 2 & 1.1 & 1.1 & 100.0 \\
\hline & Total & 188 & 100.0 & 100.0 & \\
\hline
\end{tabular}


The paramedic knowledge has increased after learning by E-learning which we can score from the post-test score with the lowest score of 38 as many as 1 person $(0.5 \%)$ and the highest score of 88 as many as $3(1.6 \%)$ and the highest score owned by the participants 73 as many as 61 people $(32.4 \%)$.

\begin{tabular}{|c|c|c|c|c|c|}
\hline \multicolumn{6}{|c|}{ Table 3 Post test scores } \\
\hline \multirow{16}{*}{ Valid } & & & & & \\
\hline & 38.00 & 1 & .5 & .5 & .5 \\
\hline & 42.00 & 1 & .5 & .5 & 1.1 \\
\hline & 46.00 & 2 & 1.1 & 1.1 & 2.1 \\
\hline & 50.00 & 3 & 1.6 & 1.6 & 3.7 \\
\hline & 54.00 & 1 & .5 & .5 & 4.3 \\
\hline & 58.00 & 3 & 1.6 & 1.6 & 5.9 \\
\hline & 62.00 & 11 & 5.9 & 5.9 & 11.7 \\
\hline & 65.00 & 14 & 7.4 & 7.4 & 19.1 \\
\hline & 69.00 & 18 & 9.6 & 9.6 & 28.7 \\
\hline & 73.00 & 61 & 32.4 & 32.4 & 61.2 \\
\hline & 77.00 & 41 & 21.8 & 21.8 & 83.0 \\
\hline & 81.00 & 27 & 14.4 & 14.4 & 97.3 \\
\hline & 85.00 & 2 & 1.1 & 1.1 & 98.4 \\
\hline & 88.00 & 3 & 1.6 & 1.6 & 100.0 \\
\hline & Total & 188 & 100.0 & 100.0 & \\
\hline
\end{tabular}

\section{Comparison of the level of knowledge} before and after e-learning utilization

Based on Wilcoxon analysis, there is a significant relationship between knowledge before and after counseling $(\mathrm{p}=$ 0.000 ) with a lower $\mathrm{P}$ value $<0.05$, it is concluded that $\mathrm{Ha}$ is acceptable.

Based on table 5 comparison of the level of paramedical knowledge before and after counseling. From the table, it was found that 1 respondent had a lower postestt score than the pretest score. A total of 178 respondents with posttest scores higher than pretest scores, and 9 respondents with posttest scores equal to pretest scores.

\begin{tabular}{|c|c|c|c|c|}
\hline & & $\mathbf{N}$ & Mean Rank & Sum of Ranks \\
\hline \multirow[t]{4}{*}{ posttest - pretest } & Negative Ranks & $1 \mathrm{a}$ & 23.50 & 23.50 \\
\hline & Positive Ranks & $178 b$ & 90.37 & 16086.50 \\
\hline & Ties & $9 \mathrm{c}$ & & \\
\hline & Total & 188 & & \\
\hline \multicolumn{5}{|c|}{ a. posttest <pretest } \\
\hline \multicolumn{5}{|c|}{ b. posttest> pretest } \\
\hline
\end{tabular}

\section{DISCUSSION}

In this study, we can see that some paramedics already have good knowledge about COVID-19. The use of e-learning in this pandemic has proven effective in increasing paramedical knowledge which we can score from the post-test score which has increased with an average value of 72 where the pre-test mean score was only 54 .

Internal training is usually carried out face-to-face, but in this pandemic era it is not possible to do so, so we need a breakthrough by using an e-learning system in the learning process. The Singapore
General Hospital has used the e learning system for a long time to improve its paramedical knowledge and it is considered to be effective. 6 However, in the research of Reni et al, the process of using e learning during this pandemic period has shortcomings. Weaknesses in the use of elearning can be in the form of signal interference, increased costs in purchasing internet quata, downed servers, low mastery of e-learning and low mastery of material in practical subjects. ${ }^{7}$ 


\section{CONCLUSION}

The use of e-learning in increasing paramedical knowledge about COVID-19 has proven to be effective, which is marked by an increase in the participants' post test scores. The difference in paramedical knowledge before and after the extension was carried out also had a significant difference with a value of $p=0.000$

\section{ACKNOWLEDGMENT}

The authors gratefully acknowledge that the present research is supported by Ministry of Research and Technology and Higher Education Republic of Indonesia. The support is under the research grant TALENTA, Contract Number Nomor: 200/UN5.2.3.2.1/PPM/2020

\section{Conflict of Interest: None}

\section{Source of Funding: None}

\section{Ethical Approval: Approved}

\section{REFERENCES}

1. Bnpb, K., Adisasmito, W., Teacher, PD, Fkm, B., \& Indonesia, U. (nd). Task Force for the Acceleration of Covid-19 Handling 1. 1-39.

2. Ministry of Health. (2020). Guidelines for the Prevention and Control of Coronavirus Disease (covid-19). 3, 1-116.
3. Susilo, A., Rumende, CM, Pitoyo, CW, Santoso, WD, Yulianti, M., Sinto, R., Singh, G., Nainggolan, L., Nelwan, EJ, Khie, L., Widhani, A. , Wijaya, E., Wicaksana, B., Maksum, M., Annisa, F., Jasirwan, OM, Yunihastuti, E., Handling, T., New, I.,... Cipto, R. (2020). Coronavirus Disease 2019: Updated Literature Review Coronavirus Disease 2019: Review of Current Literatures. 7 (1), 45-67.

4. Alhazzani, W., Møller, MH, Arabi, YM, Loeb, M., Gong, MN, Fan, E., Oczkowski, S., Levy, MM, Derde, L., Dzierba, A., \& Du, B (2020). Ssc-Covid19. Society of Critical Care Medicine, 2019.

5. Euis Karwati. (2014). Effect of e-learning learning on the quality of student learning. Journal of communication research

6. Randita Syafrandinel. 2019. Impact Of Using E-Learning Systems On Singapore General Hospital To Improve Hr Quality. Mercubuana University

7. Reni wijaya, Mustika Lukman \& Dorris Yadewani. 2020. The impact of the Covid 19 Pandemic on the use of e - learning. Dimensions: 9 (2) pp: 307 - 322

How to cite this article: Masrul, Halim S. The utilization of e-learning for improving knowledge on Covid-19 prevention and control for paramedics at Permata Bunda Hospital in Medan. International Journal of Research and Review. 2021; 8(8): 19-22. DOI: https://doi.org/ 10.52403/ijrr.20210804 